\title{
Occupational stress and employee performance: A case study of plantation companies in Riau province
}

\author{
Eddy Irsan Siregar ${ }^{a^{*}}$
}

${ }^{a}$ Muhammadiyah Jakarta University, Jl. Ahmad Dahlan 15419, Jakarta, Indonesia

\begin{tabular}{l}
\hline C H R O N I C L E \\
\hline Article history: \\
Received: November 26, 2017 \\
Received in revised format: \\
March 31, 2018 \\
Accepted: April 4, 2018 \\
Available online: \\
April 5, 2018 \\
\hline Keywords: \\
Transactional Leadership \\
Occupational Stress \\
Work Performance \\
Field Manager
\end{tabular}

\section{A B S T R A C T}

\begin{abstract}
The purpose of this research is to determine the effects of transactional leadership on occupational stress and their effects towards employee work performance using plantation companies in the Riau province as a case study. In this research, the population of the study covers all the plantation company field managers who operate in the Riau province. 196 respondents who were field managers from large plantation companies in the Riau province were taken as sample. The data analysis technique utilized in this research is the Structural Equation Modelling (SEM) analysis using the SPSS AMOS 22 program. The research results reveal that: (1) Transactional leadership has a significant effect on occupational stress. (2).Transactional leadership has no significant effects on work Performance. (3) Occupational stress has a significant effect on work performance.
\end{abstract}

\section{Introduction}

\subsection{The Potential of Palm Oil Plantation in Riau Province}

The palm oil plantation sector is currently the economic backbone of Riau Province which influences life of every society layer in Riau. After the era of petroleum, palm oil has become the most reliable source of economic movement in Riau Province. The development of palm oil plantations in the Riau province can be analogized as a snowball that is rolling and growing due to the fact that palm oil is seen a revered commodity. Big Private Plantation Companies have shown greater enthusiasm in developing palm oil plantation areas in Riau; an enthusiasm which is also shared with the locals who keen to seize these opportunities. In 2008, the breadth of palm oil plantation areas in the Riau province reached 1.54 million hectares, or equivalent to $21.89 \%$ of the total size of palm oil plantations in Indonesia. The development of palm oil plantation areas in the Riau Province until 2015 had been staggering at $2,424,544 \mathrm{~kg} .{ }^{1}$

\footnotetext{
${ }^{1}$ Book of Plantation Statistic, 2015

* Corresponding author.

E-mail address: siregareddy@gmail.com (E. I. Siregar) 
In 2015, production of palm oil plantations in Riau Province has reached 7,841,947 tons. Export commodity in Riau Province was dominantly contributed by the plantation sector, amounting to USD $6,458,898,682$; which was equivalent to $97.37 \%$ of all commodities from all other sectors in 2015 . State-owned Large Plantations (SLP) and Private Large Plantations (PLP) hold a crucial role in contributing to the Riau province. The overall size of the palm oil plantation areas in the Riau province is dominantly owned by the local people, consisting of 2,347,323 Ha (68.46\%); while SLP's have 95,855 $\mathrm{Ha}(2.69 \%)$ and PLP's have 1,027,003 Ha (28.85\%). SLP's and PLP's have become a barometer of the development and expansion of plantation industries in Riau Province, which indirectly affects the development of the local economy. The amount of SLP and PLP companies that operate in the Riau Province in 2015 reached 410 companies, where Kampar Region has 108 companies which was the highest amount. Most of the plantation companies that operate in the Riau Province are subsidiaries of Company Groups such as PTPN V, PT. Astra Agro Lestari, PT. Sinar Mas, PT. Surya Damai, PT. Indofood.

\subsection{Personal Challenges and Pressure}

The existing organizational structure in plantations directly gives power and responsibility to the field manager in managing plantations with pre-determined sizes. Field managers are given the authority and responsibility to do what they consider as appropriate to gain the most contributions for their companies in accordance with the goals that have been agreed upon. Examining the style of leadership that is used in plantation companies reveals that the typical style is Transactional Leadership; where the goals are agreed upon together as reference for the work performance of Field Manager. Work plans or goals are vital in a transactional leadership, and they must be clearly explained to the subordinates to avoid issues during the process of achieving company goals. Work goals can be a dead-weight without the support of sufficient working facilities or compensation. Field managers are most susceptible to pressure since they are the frontlines of the production efforts. The influencing factors within the production efforts are not only limited to production quantity and quality, but also include many other factors which are divided into internal and external factors. The external factors that exist in the plantation industries do not simply concern environmental problems affecting the people, but also include weather issues, climate issues, and regulations. The price of Crude Palm Oil (CPO) that fluctuates due to influences from various factors can be interpreted as a potential threat or opportunity for a manager in managing and achieving their goals. One example was in September 2015, when CPO prices experienced a sharp plunge and negatively affected the industry for the next six years. The average price of CPO throughout September went down to USD 526.9 per metric ton. This average price was 2.3 percent lower compared to the month before at USD 539.3 per metric ton (CPO, 2015).

The long drought and El Nino that took place from July to October 2015 influenced the palm trees growing which also affected production of palm oil. Water deficit values and the dry spell of studied areas were around 0-624 $\mathrm{mm}$ and 7-133 days. On the other hand, smoke pollution that occurred throughout July until October 2015 had caused a decrease of sun exposure duration and visibility up to $70 \%$. Results from observations show that the plants suffered from stress because of the drought, which was visible through the appearance of Spanish-dagger plants, a lot of male flowers, stem malformations, midrib breakage, and a lack of fruit and flower reserves (Darlan et al., 2016). The environmental concerns upon deforestation have formed a disfigured perspective towards the palm oil industry. The real matter is that these concerns are merely a result of over exaggerating by forces that have their own agendas. Roundtable Sustainable Palm Oil (RSPO) and Indonesia Sustainable Palm Oil (ISPO) certification is one of the main requirements for these plantation companies to be acknowledged as companies that are environmentally friendly.

One of the external problems that are faced in the plantation industry is the existence of people usually from the locals who make use of the locations of the companies illegally, like TBS theft, gangster activities which force people to become partners, attempt to annex lands which are not theirs using 
culture and tradition as excuses and guise. Dealing with this problem completely has not been successful. The internal factors on the other hand; cover the human resources, the means and the infrastructure and other similar concepts in the effort to achieve goals. Company goals that are specified within the work plan usually focuses upon reaching a certain quantity, but the importance of production quality also needs to be recognized. In the plantation industry, quantity and quality cannot be separated from each other since they are interconnected with one another. Field managers need to be able to achieve a balance between the goals of achieving a certain quantity, while maintaining an acceptable quality. Quantity of production can be given greater focus by the field manager to accelerate the goal achievement, but further problems would arise if the quality of production is terrible. An example of this is the Fresh Fruit Bunch (FFB) criteria that are required for the harvest of Palm Trees, and if the quantity of the raw FFB alone is given attention, it will negatively affect their quality.

Issues and limitations that exist have become obstacles in self-motivation for achieving company goals, and even a source of great pressure for the field manager. Field managers who can manage occupational stress well are commonly able to survive tough work situations and develop themselves further; while those who cannot manage their stress well, typically grow a feeling of antipathy for their works and eventually give up. Some field managers suffer from hidden declines in work motivation which lead to aversion towards their work to the point where they can no longer work due to its negative affect to their physical health. Referring to these factors, it is interested to conduct a study about "Transactional Leadership, Occupational Stress, and Work Motivation along with Work Performance (Using Plantation Companies in the Riau Province as Case Study)". The subject matters of this study are formulated as follows:

1. Transactional Leadership influence the Occupational Stress of the Field Manager

2. Environmental issue and External Force influence the occupational Stress of the Field Manager

3. Occupational Stress influence the Performance of the Field Manager

\section{Literature Review}

\subsection{Transactional Leadership}

Bass (1990) stated that transactional leadership is defined as a form of leadership which involves a process of exchange resulting in the subordinates receiving rewards which also helps them identify what they need to do to achieve what is expected from them and more; such as higher output quality, better sales and service, and reduction in production costs. Helping subordinates in identifying what their leader needs to do provides a sense of self and self-respect from the employees. The transactional approach uses the concept of goal achievement as a framework. A leader who applies the transactional leadership method helps their employees in improving their motivations to achieve the desired results through two ways; the first is that the leader needs to recognize what their subordinates need to do to achieve the expected and planned results and then clarify the role of the subordinates which in turn will make them more confident in doing their job. The second is where the leader clarifies how the fulfillment of the subordinate's needs will be exchanged with role appointment for achieving results that have been agreed upon (Bass, 1985; Khan et al., 2014).

The transactional leadership style has also been explained by Hunger and Wheelen (2003) as "a style of leadership that obtains motivation for their subordinates by promoting their own interests. The leadership behavior is focused on the results of the tasks and relationships from good employees in the exchange for desired rewards". Transactional leadership encourages the leader to adjust their style and attitude to better understand the hopes of their subordinates. According to Bycio (1995) and Koh (1995), transactional leadership is a leadership style where a leader focuses his/her attention on interpersonal transactions between the leader and his/her employees who are involved in an exchange relationship. The exchange is based on an agreement regarding target clarification, work standards, work 
assignments, and rewards. Koh (1995) stated that the transactional leadership style is formed by factors such as: contingent reward, active management by exception, and passive management by exception. These factors are further elaborated upon as the following:

\section{a. Contingent Reward}

This factor means that the subordinates receive direction from the leader regarding work procedure and goals that need to be achieved. Subordinates will receive rewards from their leader according to their abilities in following the work procedure and their success in achieving the goals that have been established.

\section{b. Active Management by Exception}

This factor explains the behavior of leaders that always do directive supervision towards their subordinates. The directive supervision in question refers to a supervision that directly observes the work process of the subordinates. It is aimed to anticipate and minimalize errors within the work process. A transactional leader will not hesitate to immediately correct and evaluate the work process of their subordinates even before the work is completed. This is done to ensure that the employees' works are within the procedure and standards that have been established.

\section{c. Passive Management by Exception}

A transactional leader will give warnings and penalties to his/her subordinates if errors are found throughout their working process. If no errors are found and the work procedures and standards are followed, no further evaluation shall be made.

Indicators of measurement for transactional leadership according to Fang and Ying (2012) are as the follows:

1. Giving positive reinforcements when jobs are completed well,

2. Giving special acknowledgments when productivity is high,

3. Giving praise when productivity is higher than usual,

4. Not acknowledging good performance,

5. Giving warnings when performance is bad,

6. Informing when productivity is not improving.

\subsection{Work Performance}

Anwar (Mangkunegara, 2002, p. 67) identified that performance (work achievements) are work results of both quality and quantity that an employee has achieved in doing his/her tasks regarding to the responsibility that has been given to him/her. The employee performance is a multiplication function of the employee's effort, which is supported by high motivation, with the employee's ability which is obtained through training. Improving performance means good performance will be the feedback for the effort or the motivation of the employee for the next step (Gomes, 1995). Performance is the level in which the employees achieve work requirements efficiently and effectively (Simamora, 2004). Employee performance is a work achievement, which is the comparison of work results that are readily visible and work standards that have been set by the organization. Then, Robbins and Judge (2008) defined performance as the results that are achieved by employees in their works following certain criteria for a job. At its roots, work appraisal is a key factor in developing an organization effectively and efficiently since there are policies or programs that are better for the human resources in the organization (Khaerul, 2010; Sadeghi \& Rad, 2018). Individual work appraisal is useful for the dynamic of 
overall organizational growth; through that appraisal, the condition of employee performance can be determined.

Employee performance is influenced by several factors (Gibson et al., 1995, p. 375) as follow:

a. The individual factor, which is the capability and skill (mental and physical), background (experience, family, etc.), and demographic (age, origin, etc.),

b. The organizational factor, resources, leadership, compensation, organizational structure, and job description,

c. The psychological factor, which is perception, attitude, personality, study pattern, and motivation.

According to Bernardin and Russel (1993)there are 6 criteria in appraising employee performance:

1. Quality, which is the degree in which processes or adjustments are made to ideally complete activities as expected.

2. Quantity, which is the amount produced through currency value, unit amount, and the amount of activity cycles that have been completed.

3. Timeliness, which is the degree in which activities have been completed faster than intended and maximizing the remaining time for other activities.

4. Cost Effectiveness, which is the degree in which utilizing the company resources such as, human resources, finance, and technology are maximized to achieve the best results or decrease losses from every unit.

5. Need for Supervision, which is the degree in which an employee can perform their work without guidance or help from their superiors.

6. Interpersonal Impact, which is the degree in which an employee feels confident, and has good intentions, and works together with colleagues.

Another opinion is provided by Dessler (2000) which stated that in appraising employee performance, 5 factors of appraisal need to be considered:

1. Quality of work, which consists of: accuracy, precision, appearance, and reception of output.

2. Quantity of work, which consists of: output volume and contribution.

3. Need of Supervision, which consists of: the need for advice, direction, or correction.

4. Attendance, which consists of: regularity, trustworthiness, and punctuality.

5. Conservation, which consists of: prevention, extravagance, damage, and equipment maintenance.

\subsection{Occupational Stress}

Every person in an organization, no matter what his/her position is, can be a source of stress for other people in the organization. Managing self-stress means controlling oneself in life. As a manager, managing stress is more about understanding the cause of stress for others and taking action to reduce that stress to achieve the organization goals. The effectiveness of the two-way communication process between the manager and employee is important to identify the cause of stress and its possible solution, because stress will always haunt the employees (Qureshi et al., 2012). Stress is an imbalance between desires and the ability to fulfill them, which inflict important consequences for those who suffer from stress. Stress is a dynamic condition in which an individual is confronted with opportunities, obstacles, and desires, where the results that they would achieve are crucial yet uncertain (Robbins \& Judge, 2008, p. 368). Even though there are several definitions and debate regarding the definition of Occupational Stress, Fred (2006, p. 440) defined it as "an interaction between an individual and the environment," which is then explained in more detail as: "an adaptive response that is connected by individual differences and/or psychological processes which are consequences of action, situation, or external events (environment) that have an overbearing psychological or physical requirement on someone." Generally, a person who is experiencing Occupational Stress will show symptoms that revolve around 3 
aspects, which are: Physiological, Psychological, and Behavior (Epitropaki \& Martin, 2005, pp. 800802). Here are examples of symptoms of each aspects :

1. Physiological, is indicated by: the occurrence of change in metabolism, an increase in breath and heartbeat intensity, an increase in blood pressure, headaches, and the possibility of heart attacks.

2. Psychological, is indicated by: dissatisfaction in work relations, tenseness, agitation, worry, temper issues, boredom, and procrastination.

3. Behavior, is indicated by: a change in productivity, non-attendance of work schedules, a change in appetite, increased usage of cigarettes, increased consumption of alcohol, speaking with faster intonations, easily agitated, and difficulty in sleeping.

\subsection{Thought Framework}

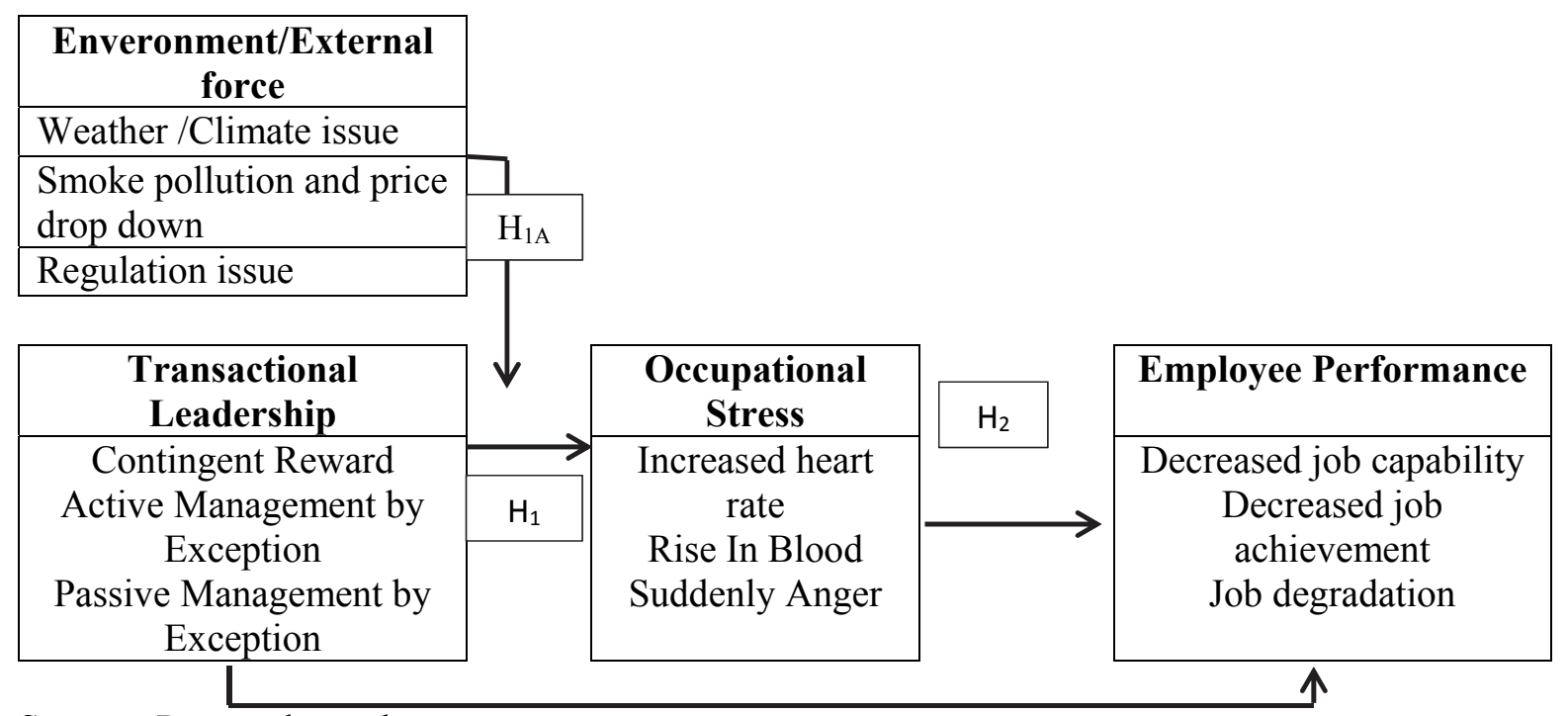

Source : Process by author

Fig. 1. Thought Framework

Based on theoretical thought frameworks that have been explained, the hypotheses suggested by this research are as the follow,

H1: Transactional Leadership influence the Occupational Stress of the Field Manager

H1A: Environment issue and External Force (as Moderator Variable) influence on the occupational Stress of the Field Manager

H2: Occupational Stress influence the Performance of the Field Manager

\section{Research Methodology}

\subsection{Type and Source of Data}

The type and source of data used in this research are primary data. Primary data are research data that are obtained directly from the original source (without any intermediaries). Primary data are specifically gathered by the researcher to answer the research (Indriantoro \& Supomo, 1999) or directly interact with the issue being studied (Cooper Donald \& Emory, 1998, p. 258). Primary data that are needed in this research related to variables for stress, leadership, and motivation towards performance of the Field Manager. These data were obtained through questionnaires that had been prepared by the researcher and answered by respondents who are actual Field Managers. 


\subsection{Population}

The population for this research is all the field managers from all plantation companies in the Riau province, which amount to 410 companies. Every plantation is led by a field manager with a plantation size below 600 to $1000 \mathrm{Ha}$. Samples or respondents for this research are taken from large plantation companies that have been established for more than 10 years, from both SLPs and PLPs, which amount to 196 respondents. According to Ferdinand (2005, p. 43), the size of sample appropriate to use is between 100 and 200. If the sample size is too large, for example more than 400, the method becomes overly sensitive which makes it difficult to obtain suitable goodness-of-it measurements. In the opinion of Hair, et al. (1995), regarding research that uses the SEM analysis technique, samples for a research will be considered representative if consist of at least 100 respondents. In this research, the method that is used is a census through giving out questionnaires for the whole population which amounts to 196 people who are Department Assistants, Head Assistants, and Assistants of Affairs in the Field of Plants from all Units or Plantations.

\subsection{Data Gathering Technique}

Data were gathered using questionnaires by providing a list of closed questions directly to the respondents. The questionnaires consist of 2 parts, the first part contains questions to obtain personal information about the respondents and the second part is used to obtain data regarding dimensions of constructs that are developed within this research. In this part, the respondent attitude towards each question are measured with scales, ranging from 1 to 5, to obtain interval data and to be given scores; for example, to state if the person agrees or disagrees.

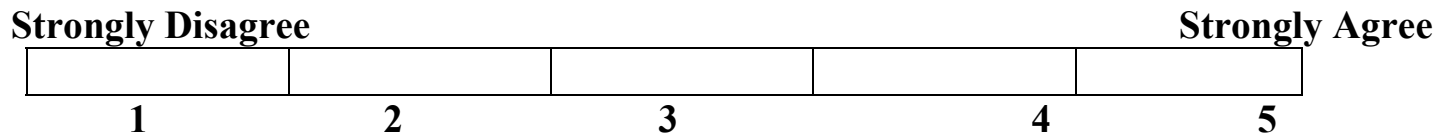

\subsection{Data Analysis Technique}

This research needs a form of data analysis and interpretation that will be used to answer the research questions and reveal particular social phenomenon, so that the data will be more easily read. The model of research that will be used is the one that has a tiered structure and for testing the suggested hypothesis. The SEM (Structural Equation Modelling) analysis technique will be used; which is proceed by AMOS. The reason for using SEM is because it is a group of statistical techniques that makes it possible to test a series of relationships that are relatively "complex" simultaneously. Modeling by SEM enables a researcher answer research questions that are regressive or dimensional (which is measuring the dimensions of a concept (Ferdinand, 2005). Analyzing research models through SEM enable to identify dimensions of a construct and at the same time measure the influence or degree of relation between factors whose dimensions have been identified.

\section{Results and Findings}

\subsection{Results}

\subsubsection{Examination of Research Instruments}

The validity of instruments is examined using the Pearson Correlation analysis tool between items and total items. If the value of correlation is above 0.30 , it indicates that the item is valid. On the other hand, if the value of correlation is below 0.30 , it indicates that the item is not valid and shall not be included for the next step (Sugiyono, 2003). Reliability of the instruments is examined using the Alpha Cronbach analysis tool. If the Alpha Cronbach coefficient value is above 0.60, that indicates a reliable instrument; on the other hand, if the Alpha Cronbach coefficient value is below 0.60, that indicates that the instrument is not reliable(Sugiyono, 2003). Table 1 shows that the Transactional Leadership has a correlation value 
above 0.30 , soall the Items can be determined as valid. It also shows that the Alpha Cronbach coefficient value is above 0.60 , so the Transactional Leadership instrument variable is determined as valid and reliable.

\section{Table 1}

Validity and Reliability Test for Transactional Leadership Variable

\begin{tabular}{cccc}
\hline Variable & Indicator/Item & Correlation & Information \\
\hline & $\mathrm{X} 1.1$ & 0,457 & Valid \\
& $\mathrm{X} 1.2$ & 0,514 & Valid \\
& $\mathrm{X} 1.3$ & 0,496 & Valid \\
& $\mathrm{X} 1.4$ & 0,407 & Valid \\
& $\mathrm{X} 1.5$ & 0,662 & Valid \\
Transactional Leadership & $\mathrm{X} 1.6$ & 0,664 & Valid \\
& $\mathrm{X} 1.7$ & 0,383 & Valid \\
& $\mathrm{X} 1.8$ & 0,403 & Valid \\
& $\mathrm{X} 1.9$ & 0,414 & Valid \\
& $\mathrm{X} 1.10$ & 0,477 & Valid \\
& $\mathrm{X} 1.11$ & 0,829 & Valid \\
& $\mathrm{X} 1.12$ & 0,432 & Valid \\
\hline
\end{tabular}

Table 2

Validity and Reliability Test for Occupational Stress Variable

\begin{tabular}{cccc}
\hline Variable & Indicator/Item & Correlation & Information \\
\hline & Y1.1 & 0,661 & Valid \\
& Y1.2 & 0,711 & Valid \\
& Y1.3 & 0,635 & Valid \\
Occupational Stress & Y1.4 & 0,508 & Valid \\
& Y1.5 & 0,780 & Valid \\
& Y1.6 & 0,429 & Valid \\
& Y1.7 & 0,587 & Valid \\
& Y1.8 & 0,553 & Valid \\
& Y1.10 & 0,507 & Valid \\
& Y1.11 & 0,860 & Valid \\
\hline
\end{tabular}

Table 2 shows that all the indicators of the Occupational Stress variable have correlation values above 0.30 , so the Indicators are determined as valid. The Alpha Cronbach coefficient value is above 0.60, so the Occupational Stress variable instrument is determined as valid and reliable. The Table 3 shows the examination of the Motivation variable.

\section{Table 3}

Validity and Reliability Test for Performance Variable

\begin{tabular}{lccc}
\hline Variable & Indicator/Item & Correlation & Information \\
\hline & Y3.1 & 0,713 & Valid \\
& Y3.2 & 0,796 & Valid \\
& Y3.3 & 0,796 & Valid \\
& Y3.4 & 0,704 & Valid \\
& Y3.5 & 0,803 & Valid \\
& Y3.6 & 0,710 & Valid \\
Performance & Y3.7 & 0,713 & Valid \\
& Y3.8 & 0,848 & Valid \\
& Y3.9 & 0,750 & Valid \\
& Y3.10 & 0,532 & Valid \\
& Y3.11 & Valid \\
& Y3.12 & 0,480 & Valid \\
& Y3.13 & 0,535 & Valid \\
\hline
\end{tabular}


Table 3 shows that all the items in the Performance variable have correlation values above 0.30 , so the Indicators are determined as valid. The Alpha Cronbach coefficient value is above 0.60 , so the Performance variable instrument is determined as valid and reliable.

\subsubsection{Examination of Research Model}

\section{a. Goodnesss of Fit SEM}

The result of the goodness of fit overall model examination, according to the results of the SEM analysis, to know if the hypothesis model is supported by empiric data, is presented in Fig. 2.

Table 4

Examination Results for Goodness of Fit Overall Model Stage I

\begin{tabular}{lccl}
\hline Criteria & Cut-off value & Model Result & Information \\
\hline Chi Square & $\mathrm{df}=195 ;$ Sig $5 \%=228,580$ & 290.576 & Deficient Model \\
CMIN/DF & $\leq 2.00$ & 2.965 & Deficient Model \\
GFI & $\geq 0.90$ & 0.862 & Deficient Model \\
AGFI & $\geq 0.90$ & 0.808 & Deficient Model \\
TLI & $\geq 0.95$ & 0.888 & Deficient Model \\
CFI & $\geq 0.95$ & 0.908 & Deficient Model \\
RMSEA & $\leq 0.08$ & 0.100 & Deficient Model \\
\hline
\end{tabular}

Referring to the Goodness of Fit Overall examination presented on the Fig. 2 and Table 4, all the criteria show values that are less than good. Therefore, a modification of the model is needed to obtain a more appropriate model.

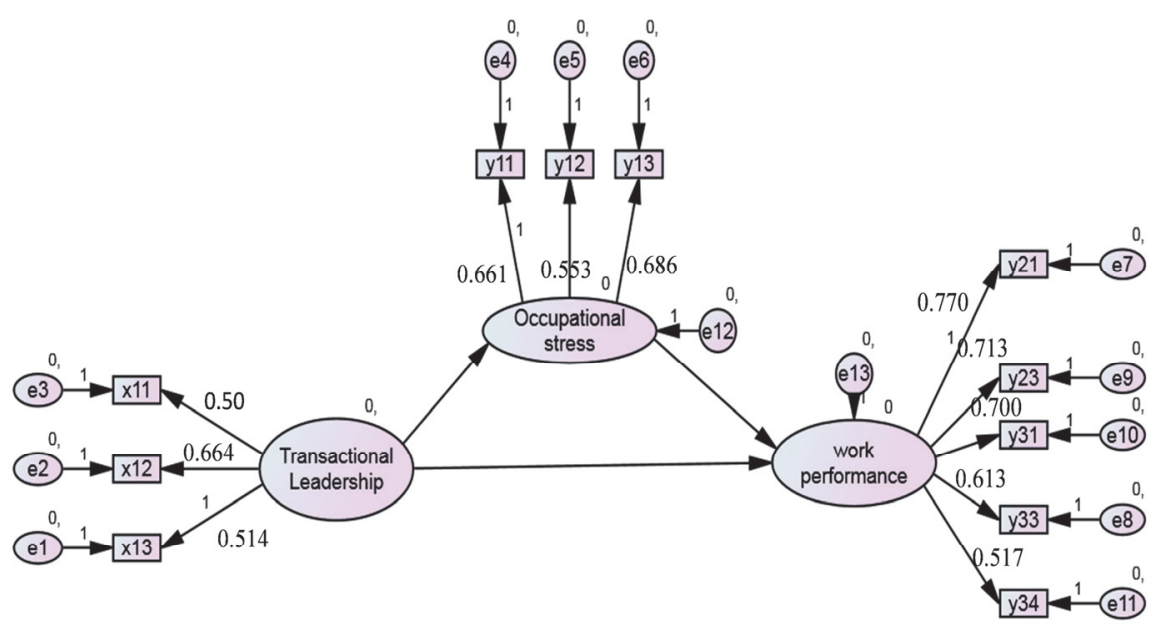

Table 5

Fig. 2. Structural Model Graphic for SEM Stage I

Examination Results for Goodness of Fit Overall Model Stage II

\begin{tabular}{lccc}
\hline Criteria & Cut-off value & Model Result & Information \\
\hline Chi Square & $\mathrm{df}=195 ;$ Sig $5 \%=228,580$ & 156.425 & Good Fit \\
CMIN/DF & $\leq 2.00$ & 1.700 & Good Fit \\
GFI & $\geq 0.90$ & 0.912 & Good Fit \\
AGFI & $\geq 0.90$ & 0.870 & Marginal \\
TLI & $\geq 0.95$ & 0.960 & Good Fit \\
CFI & $\geq 0.95$ & 0.969 & Good Fit \\
RMSEA & $\leq 0.08$ & 0.060 & Good Fit \\
\hline
\end{tabular}


The results of the Goodness of Fit Overall examination on Fig. 3 and Table 5 show that there are 6 criteria that fulfill the Cut-of value so that the model can become feasible. Therefore, the SEM model used in this research is feasible to use, and interpretations can be done to discuss the topic further.

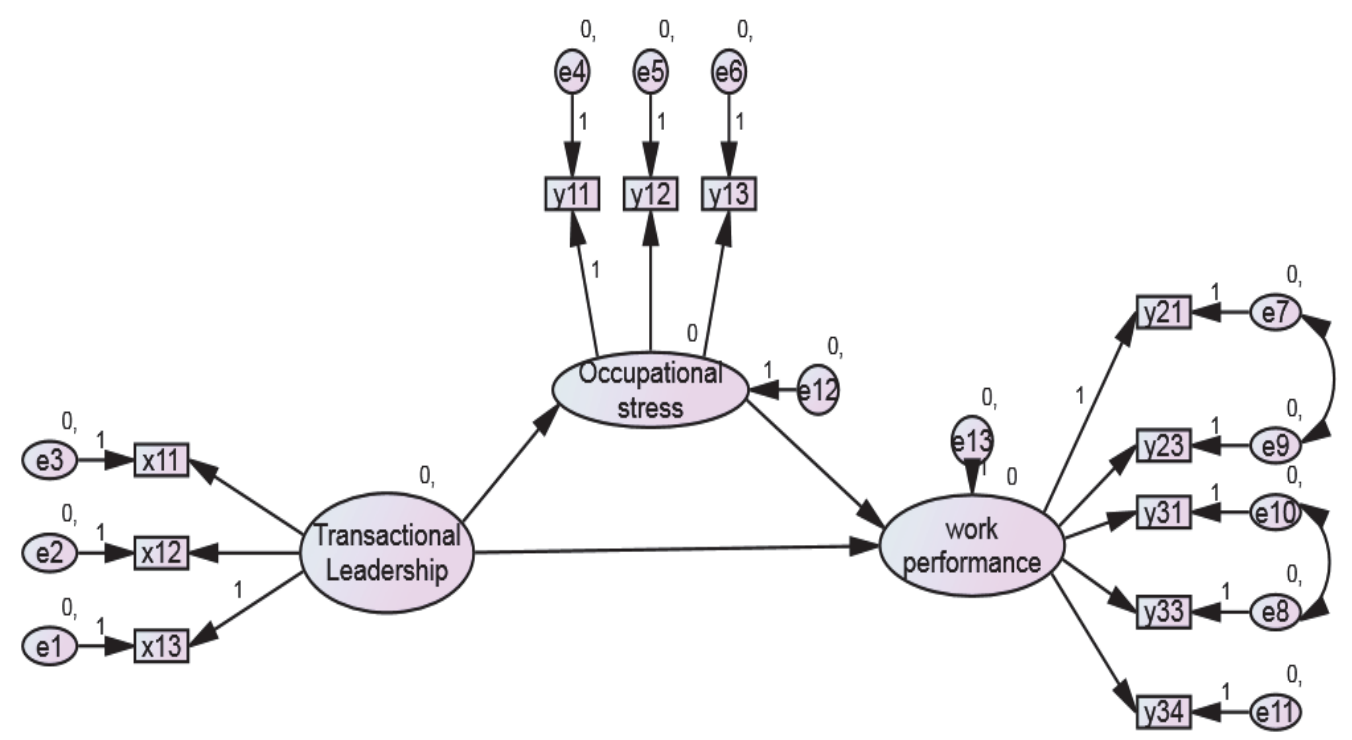

Fig. 3. Structural Model Graphic for SEM Stage II

\section{b. SEM Assumption Examination}

\section{Normality}

Referring to the results of the SPSS AMOS 22 data processing on appendix 1, a critical ratio value of -0.076 while a $Z_{\text {count }}$ critical value for $\alpha=5 \%$ is $\pm 1,96$. Since the absolute $C R$ value for the multivariate is $-0.076>-1.96$, the normality assumption of the multivariate is fulfilled.

\section{Outlier}

Examination of outliers multivariate is conducted using Mahalanobis criteria at the level of $p<0.001$. Mahalanobis distance is evaluated using $\chi^{2}$ on a free degree as much as the parameter in the used model which is $=67$, where from the statistic table a value of $\chi_{67}^{2}=108,526$. From the Mahalanobis distance table on appendix 2, it can be seen that the point of observation that is the furthers is the $131^{\text {st }}$ respondent, with the value of $\mathrm{Md}=37.194$. Comparing the value $\chi_{67}^{2}=108,526$, value of the $131^{\text {st }} \mathrm{Md}$ point $<$ 108.526; then it can be concluded that all points of observation are not outliers.

\section{Measurement Model}

The measurement model measures the loading factor (standardize coefficient) values of all indicators towards the latent variable. The value of the loading factor shows the weight of each indicator as a measurement of each variable. Indicators with loading factor show that those indicators are the strongest variable measurers.

Analysis results of the confirmatory factors for the indicators of each of the 4 variables are presented as the following: 
Table 6

Results of Transactional Leadership Measurement Model Examination (X)

$\begin{array}{ccc}\text { Dimension } & \text { Standardize } & \text { P-Value } \\ \text { Contingent Reward } & 0,708 & 0.000 \\ \text { Active Mgt by Exception } & 0,787 & 0.000 \\ \text { Passive Mgt by Exception } & 0,689 & \text { FIX }\end{array}$

Table 6 shows the standardized coefficient value or loading factor for each indicator of the Transactional Leadership variables. The highest standardized coefficient value or loading factor is the Dimension of Active Management by Exception followed by the Contingent Reward and Passive Management by Exception.

Table 7

Results of Occupational Stress Measurement Model Examination (Y1)

\begin{tabular}{ccc}
\hline Indicator & Standardize & P-Value \\
\hline Physiological $($ Y1.1) & 0,718 & FIX \\
Psychological $($ Y1.2) & 0,713 & 0.000 \\
Behavior $($ Y1.3) & 0,685 & 0.000 \\
\hline
\end{tabular}

Table 7 shows the standardized coefficient value or loading factor for each indicator of the Occupational Stress variables. The highest standardized coefficient value or loading factor is the Physiological indicator followed by the Psychological and Behavior indicators.

Table 8

Results of Performance Measurement Model Examination (Y3)

\begin{tabular}{ccc}
\hline Indicator & Standardize & P-Value \\
\hline Quantity (Y3.1) & 0,770 & FIX \\
Quality (Y3.2) & 0,837 & 0.000 \\
Punctuality (Y3.3) & 0,772 & 0.000 \\
Attendance (Y3.4) & 0,843 & 0.000 \\
Teamwork (Y3.5) & 0,836 & 0.000 \\
\hline
\end{tabular}

Table 8 shows the coefficient standardize value or loading factor for each indicator of Performance. The highest coefficient standardize value or loading factor is the Attendance indicator followed by the Quality, Teamwork, Punctuality, and Quantity.

\section{Structural Model}

\section{Table 10}

SEM Hypothesis Examination

\begin{tabular}{lcccc}
\hline \multicolumn{1}{c}{ Variable Relations } & Coefficient & CR & P-value & Information \\
\hline Transactional Leadership $\rightarrow$ Occupational & $-0,824$ & $-7,394$ & 0,000 & Significant \\
Stress & 0,160 & 1,201 & 0,230 & Insignificant \\
Transactional Leadership $\rightarrow$ Performance & $-0,451$ & $-3,034$ & 0,002 & Significant \\
Occupational Stress $\rightarrow$ Performance & & \\
\hline
\end{tabular}

The result of data processing is simultaneusly presented as the following :

Referring to the tables and picture above, the results of the hypothesis examination on a structural model can be described as follows:

\section{a. Direct Effect}

1. The direct effect of Transactional Leadership towards Occupational Stress has the coefficient of -0.824 with the Critical Ratio -7.394 and p-value of $0.000<$ alpha $(0.05)$. It can be concluded that Transactional Leadership has a significant effect on Occupational Stress. These two variables 
have a negative correlation, meaning that the higher the Transactional Leadership, the lower the Occupational Stress.

2. The direct effect of Transactional Leadership towards Performance has the coefficient of 0.160 with the Critical Ratio 1.201 and p-value of $0.230>$ alpha (0.05). It can be concluded that Transactional Leadership does not have a significant effect on Performance. These two variables have a positive correlation, meaning that the higher the Transactional Leadership, the higher the Performance.

3. The direct effect of Occupational Stress towards Performance has the coefficient of -0.451 with the Critical Ratio -3.034 and p-value of $0.002<$ alpha (0.05). It can be concluded that Occupational Stress has a significant effect on Performance. These two variables have a negative correlation, meaning that the higher the Occupational Stress, the lower is the Performance.

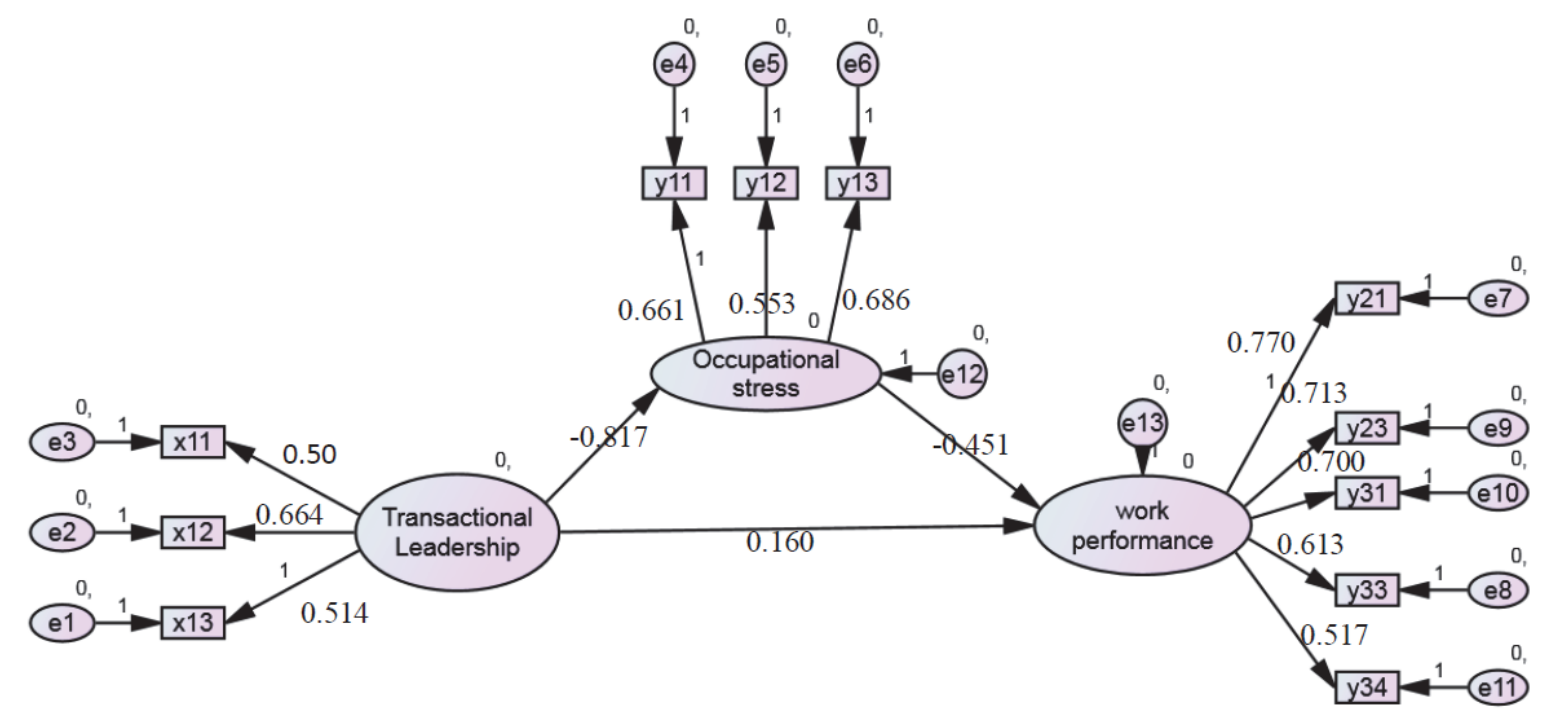

Fig. 4. Structural Model Graphic in the Last Stage of SEM

\subsection{Discussion}

This section of the paper will discuss the results of the research with the main purpose of answering whether the hypothesis that has been formulated earlier is acceptable or not.

\section{Effects of Transactional Leadership on Occupational Stress}

The result reveals that Transactional Leadership has a direct influence on Occupational Stress which is both significant and negative. It can be concluded that the better the Transactional Leadership is applied by the Field Manager, the less Occupational Stress will be. Conversely, where the worse the Transactional Leadership is applied, The Occupational Stress will increase. Transactional Leadership contributes directly towards Occupational Stress at67.90\%, which means that the change in Occupational Stress is affected by proper Transactional Leadership as much as $67.90 \%$.

\section{The Effects of Occupational Stress on Performance}

The resulst reveals that Occupational Stress has a direct influence on Performance which is both significant and negative. This research concludes that the heavier Occupational Stress felt by the Field Manager, the Performance will decrease. Conversely, The less Occupational Stress will improve the Performance. The direct contribution that is provided by Occupational Stress towards Performance is as much as $20.34 \%$, which means that the change in Performance for to the Field Manager is affected by strong Occupational Stress at $20.34 \%$. 


\section{Conclusion}

Referring to the research title, main issues, research objective, formulation of hypothesis, and discussion of research outcomes, it can be concluded that Transactional Leadership had a significant and negative effect on Occupational Stress. It means that the practice of Transactional Leadership Style will decrease the Occupational Stress, in this case, The Field Managers. This leadership style did not have significant effect on Performace, however the correlation between the two variables was negative. It indicates that in this case a better Transactional Leadership may improve the Performance of the Field Managers. Occupational Stress was revealed to have a significant and negative effect on

Performance. It shows that lower Occupational Stress will improve the Performance of the Field Managers.

\section{References}

Bass. (1985). Leadership and Performance Beyond Expectation. New York: Free Press.

Bass, B. M. (1990). From Transactional to Transformational Leadership, Learning to Share the Vision, Organizational Dynamics (winter).

Bernardin, J. H., \& Joyce, E. A. R. (1993). Human Resource Management An Experiental Approach. Singapore: McGraw Hill Series in Management.

Bycio P., H. R., Allen J. (1995). Further Assesments of Bass's (1985) Conceptualization of Transactional and Transformational Leadership. Application Psychology, 80, 468-478.

CPO. (2015). Harga CPO Terendah Enam Tahun Terakhir.

Cooper Donald, R. C., \& Emory, W. (1998). Metode Penelitian Bisnis. Erlangga, Jakarta.

Darlan, N. H., Pradiko, I., \& Siregar, H. H. (2016). Effect of El Nino 2015 on Oil Performance in Southeastern Part of Sumatera. Indonesian Soil and Climate Journal, 40.

Dessler, G. (2000). Human Resource Management. New Jersey: Prentice Hall Inc.

Epitropaki, O., \& Martin, R. (2005). The moderating role of individual differences in the relation between transformational/transactional leadership perceptions and organizational identification. The Leadership Quarterly, 16, 569-589.

Fang, C., \& Ying, Y. (2012). The Effects of Transactional and Transformational Leadership on Organizational Commitment in Hotels: The Mediating Effects of Trust. Hotel and Business Management, 1(1), 6-8.

Ferdinand, A. T. (2005). Structural Equation Modeling dalam Penelitian Manajemen. Semarang: Universitas Diponegoro.

Fred, L. (2006). Perilaku Organisasi. Yogyakarta: Andi.

Gibson, J. L., Ivancevich, J. M., \& Doonely, J. H. (1995). Organisasi (Jarkasih, Trans.). Jakarta: Erlangga.

Gomes, F. C. (1995). Manajemen Sumber Daya Manusia. In. Yogyakarta: Andi.

Indriantoro, N., \& Supomo, B. (1999). Metodologi Penelitian Bisnis Untuk Akutansi dan Manajemen. Yogyakarta: BPFE.

Hair Jr, J. F. H., Tatham, R. E. A. R. L., \& Black, W. C. (1995). Multivariate Data Analysis with Readings. Eaglewoods Cliffs, NJ: Prentice Hall Inc.

Khaerul, U. (2010). Perilaku Organisasi. Bandung: CV Pustaka Setia.

Khan, M. I., Awan, U., Yasir, M., Mohamad, N. A. B., Shah, S. H. A., Qureshi, M. I., \& Zaman, K. (2014). Transformational leadership, emotional intelligence and organizational commitment: Pakistan's services sector. Argumenta Oeconomica, 33(2), 67-92.

Koh, W. L., RM, S., \& JR, T. (1995). The Effect of Transformational Ledership on Teacher Attitudes and Students Performance in Singapore. Organizational Behavior, 16, 319-333.

Hunger, J. D., \& Wheelen, T. L. (2003). Manajemen strategis. Yogyakarta: Andi.

Mangkunegara, A. P. (2002). Manajemen Sumber Daya Manusia Perusahaan. Bandung: PT. Remaja Rosdakarya. 
Qureshi, I., Jamil, R. A., Iftikhar, M., Arif, S., Lodhi, S., Naseem, I., \& Zaman, K. (2012). Job stress, workload, environment and employees turnover intentions: Destiny or choice.

Robbins, P. S., \& Judge, A. T. (2008). Perilaku Organisasi (Angelica, Trans. Vol. 12 ). Jakarta: Salemba.

Sadeghi, A., \& Rad, F. (2018). The role of knowledge-oriented leadership in knowledge management and innovation. Management Science Letters, 8(3), 151-160.

Simamora, H. (2004). Manajemen Sumber Daya Manusia. In (Vol. 3). Yogyakarta: Bagian Penerbitan Sekolah Tinggi Ilmu Ekonomi YKPN.

Sugiyono. (2003). Metode Penelitian Bisnis. Bandung: CV. Alfabeta.

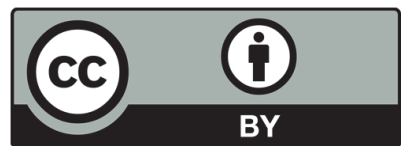

(C) 2018 by the authors; licensee Growing Science, Canada. This is an open access article distributed under the terms and conditions of the Creative Commons Attribution (CC-BY) license (http://creativecommons.org/licenses/by/4.0/). 